\title{
Squamous cell carcinoma of the breast - A rare entity
}

\section{Latha PS ${ }^{1}$, Chaitanya $\mathrm{B}^{2}$, Rajasekhar $\mathrm{SR}^{3}$}

${ }^{1}$ Dr P Swarna Latha, MD, Nizam's Institute of Medical Sciences, Hyderabad Andhra Pradesh 2 Dr Balekuduru Chaitanya, MD, Dr NTR University of Health Sciences Vijaywada Andhra Pradesh ${ }^{3}$ Dr S. Rajasekhar Reddy, M.D, Nizam's Institute of Medical Sciences, Hyderabad Andhra Pradesh

Address for correspondence: Dr Balekuduru Chaitanya, Email: bharadwaj.chaitanya@yahoo.com

\begin{abstract}
Primary squamous cell carcinoma (SCC) of the breast is a rare tumour classified as one of the metaplastic carcinomas of the breast. It is a tumour of elderly age group with an incidence of less than $0.1 \%$ of all ductal carcinomas. Clinical and biological characteristics of this tumour still remain obscure. The prognosis of this type of breast cancer remains a subject of controversy. We report one such case of primary squamous cell carcinoma of breast with review of literature.
\end{abstract}

Keywords: Squamous cell carcinoma, Breast, Prognosis, SCC

\section{Introduction}

Squamous cell carcinoma of the breast is an uncommon tumour that is diagnosed when more than $90 \%$ of the malignant cells are of the squamous type. ${ }^{1}$ In order to make this diagnosis one must exclude an epidermal origin from the nipple and overlying skin and the possibility of metastases from squamous cell malignancies from skin, cervix, oropharynx, lung, oesophagus, stomach and urinary bladder. ${ }^{2}$ In the present report these conditions for pure squamous cell carcinoma are fulfilled. The findings are discussed in light of the existing literature in this field.

\section{Case report}

A 45 year old woman presented with a mass in her left breast of 1 month duration. She has attained menopause one year back. Physical examination revealed a firm mass occupying whole of the left breast with irregular margins

Manuscript received: $16^{\text {th }}$ July 2013

Reviewed: $26^{\text {th }}$ July 2013

Author Corrected: $11^{\text {th }}$ Aug 2013

Accepted for Publication: 20 $0^{\text {th }}$ Aug 2013 measuring approximately 13 x $12 \mathrm{cms}$. Mass was freely mobile over the chest wall and overlying skin was erythematous. Contralateral breast and bilateral axillae were normal on palpation. Chest $\mathrm{X}$ ray and abdominal ultrasound were within normal limits. With a clinical suspicion of inflammatory carcinoma, a trucut biopsy was performed. Tumour was diagnosed as squamous cell carcinoma for which the patient received 3 cycles of neoadjuvant chemotherapy with Cyclophosphamide, Adriamycin and 5 Fluoro uracil. As thought as a partial clinical response the tumour regressed in size, developed surface ulceration with fistula formation and pus discharge. The she underwent a modified radical mastectomy of the left breast with ipsilateral axillary lymph node dissection and skin grafting.

Grossly, a grey white ill defined tumour measuring 5 x 4 cms was located in the upper inner and outer quadrant of the breast. The central portion of the tumour showed extensive necrosis. 
Microscopic examination from the lesion showed nests, sheets, trabeculae of pleomorphic polygonal cells with vesicular nuclei, prominent nucleoli and abundant amount of eosinophilic cytoplasm. Individual cell keratinization, keratin pearl formation and frequent mitoses were also noted. Metastases were seen in 4 out of 6 lymph nodes. Figures 1 and 2 are enclosed depicting microscopy. The tumour was negative for estrogen and progesterone receptors on immunohistochemistry. A final opinion of grade II (moderately differentiated) squamous cell carcinoma with PT4bPT2PMx staging was provided. Additionally lymphatic invasion was present and no vascular invasion or microcalcifications were noted. Patient was kept on neoadjuvant chemotherapy and follow up so far was normal.

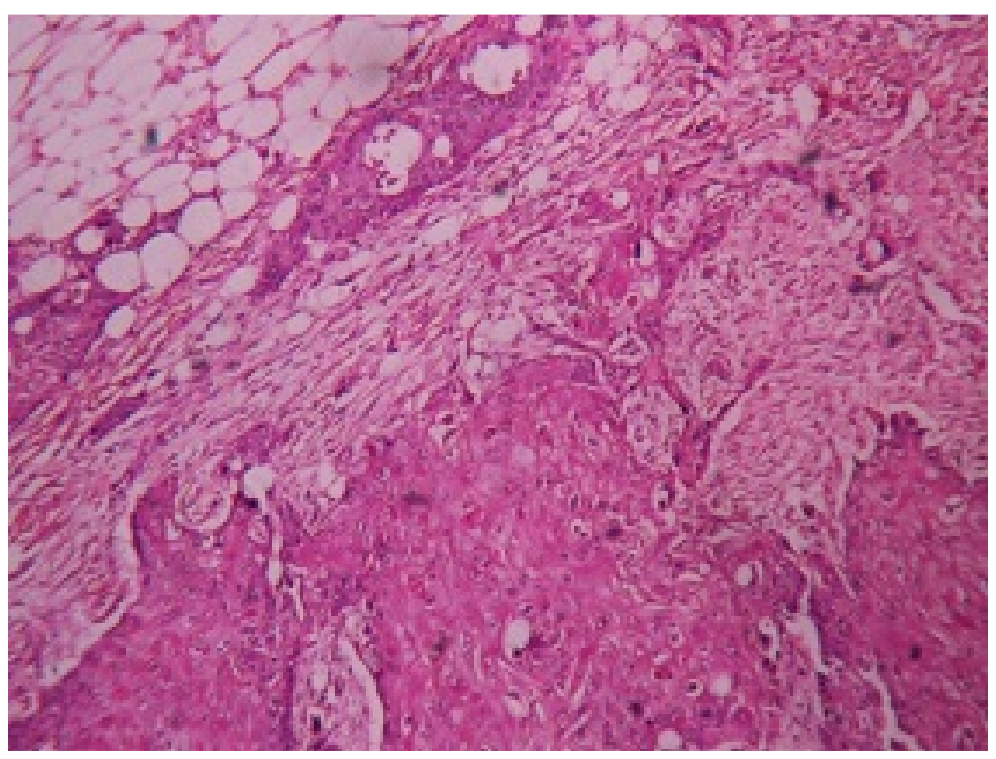

Figure 1: Microphotograph showing squamous islands with adjacent fat, H\&E, 100x

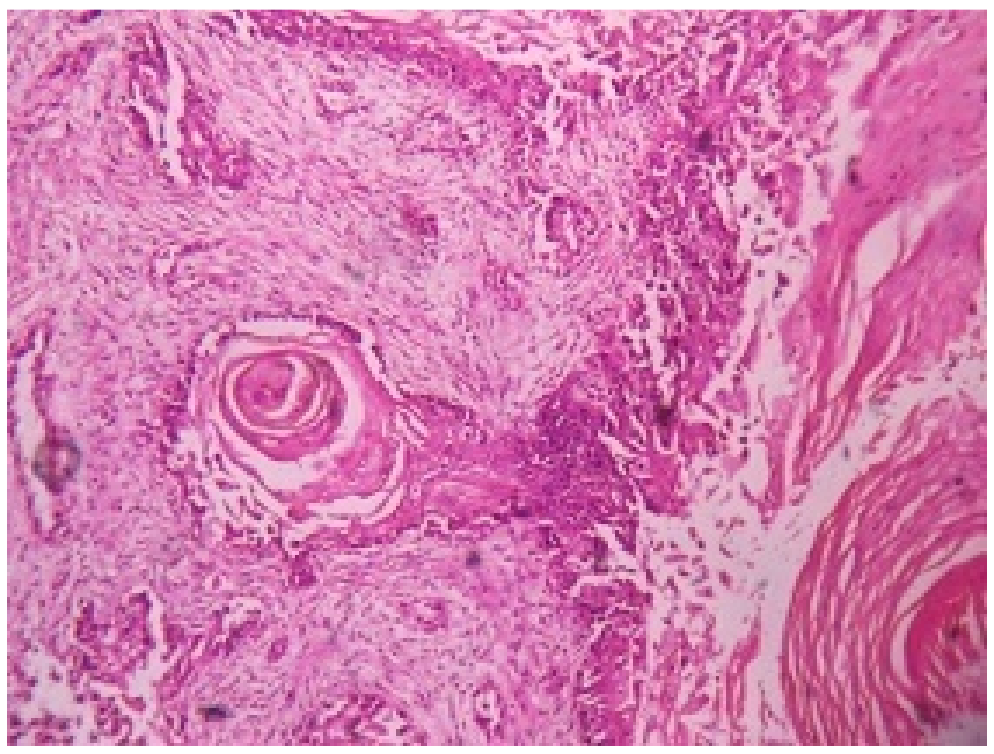

Figure 2: Microphotograph showing neoplastic squamous cells with adjacent keratin pearls \& fibrous stroma, H\&E, 100x 


\section{Discussion}

Primary squamous cell carcinoma is a very rare tumour of the breast. The first case was reported in 1908 by Troell. ${ }^{3}$ It's histogenesis is unclear. Some authors suggest a metaplastic origin from ductal epithelium while some consider it as a complication of chronic breast inflammation. $^{4}$

It predominantly affects postmenopausal women. It tends to be somewhat larger at presentation than the other types of breast carcinoma with more than $50 \%$ of the reported cases being in excess of $5 \mathrm{cms}$ in diameter.,

Histology is similar to squamous cell carcinoma elsewhere in the body. Immunohistochemistry could be a useful tool to distinguish cutaneous SCC and a primary SCC of breast. Both of these tumours are positive for HMW-CK whereas primary breast tumours generally have CK19, CK7 and CK8 staining contrary to the cutaneous SCC. ${ }^{7,8,9}$ Most of these tumours are ER \& PR negative. So is our case.

Similarities exist in the clinical behavior of basal type of breast cancers and breast SCC. ${ }^{10}$ Study of SCC of breast for basal or myoepithelial markers and gene profiling may throw light into its carcinogenesis.

Prognosis of SCC breast is somewhat controversial. The high frequency of EGFR positivity in these tumours needs to be studied for exploration of targeted therapy along with synergistic cytotoxics such as platinums and taxanes. New case reports would help to determine the right approach to this disease.

\section{Funding: Nil}

Conflict of interest: Nil

Permission from IRB: Yes

\section{References}

1. Rosen PR: Rosen's Breast Pathology. Philadelphia, PA: Lippincott Williams \& Wilkins; 2001.Chapter 19, p. 455461.
2. Zoltan TB, Konick L, Coleman RJ. Pure squamous cell carcinoma of the breast in a patient with previous adenocarcinoma of the breast: a case report and review of the literature. Am Surg.2001; 67(7): 671-3.

3. Troell A: Zwei Falle von Palttenepithelcarcinom. Nord Med Ark.1908; 1:1-11.

4.Cardoso F, Leal C, Meira A, Azevedo R, Mauricio MJ, Leal da Silva JM, Lopes C, Pinto Ferreira E. Squamous cell carcinoma of the breast. Breast. 2000;9(6): 315-9.

5. Behranwala KA, Nasiri N, Abdullah N, Trott PA, Gui GP. Squamous cell carcinoma of the breast: clinicopathologic implications and outcome. Eur J Surg Oncol. 2003; 29: 386-9.

6. Moisidis E, Ahmed S, Carmalt H, Gillett D. Primary squamous cell carcinoma of the breast. ANZ J

Sur. 2002;72:65-67. doi: 10.1046/j.1445-

2197.2002.02298.x.

7. Ciocca V, Bombonati A, Gatalica Z, Di Pasquale M, Milos A, Ruiz-Orrico A, Dreher D, Folch N, Monzon F, Santeusanio G, Perou CM, Bernard PS, Palazzo JP. Cytokeratin profiles of male breast cancers.

Histopathology. 2006; 49(4):365-70.

\section{Abd El-Rehim DM, Pinder SE, Paish CE, Bell}

J, Blamey RW, Robertson JF, Nicholson RI, Ellis IO. Expression of luminal and basal cytokeratins in human breast carcinoma. J Pathol. 2004; 203(2):661-71.

9. Gal-Gombos EC, Esserman LE, Recine MA, Poppiti RJ Jr. Large-needle core biopsy in atypical intraductal epithelial hyperplasia including immunohistochemical expression of high molecular weight cytokeratin: analysis 
of results of a single institution. Breast J. 2002;8(5):269-

74.

\section{How to cite this article?}

Latha PS, Chaitanya B, Rajasekhar SR. Squamous cell carcinoma of the breast - A rare entity. Int J Med Res Rev 2013;1(3):134-137.
10. Korbling M, Estrov Z: Adult stem cells for tissue repair: A new therapeutic concept? N Engl J Med.2003; 349:570-582. 